\title{
Semantic Differential as One of the Research Tools Suitable for Establishing the Attitudes of Pupils to Old Age and Seniors
}

\author{
Soňa Divilová \\ Faculty of Education, Palacky University in Olomouc, Czech Republic
}

Copyright $(\mathrm{C} 2016$ by authors, all rights reserved. Authors agree that this article remains permanently open access under the terms of the Creative Commons Attribution License 4.0 International License

\begin{abstract}
The paper presents the results of the pre-research conducted under the project entitled "Seniors in the Eyes of Children". The main objective of the project was to create and test a research tool in order to establish what the attitudes of pupils to old age and seniors were. Semantic differential was chosen for these purposes. Semantic differential serves to map attitudes, penetrates the deeper layers of thinking, and tries to understand the individual meanings of words and the feelings of respondents. The paper primarily deals with the semantic differential method, the preparation and implementation of the pre-research, the process of creation of the research tool, and the individual steps in the collection and evaluation of data.
\end{abstract}

Keywords Pre-research, Semantic Differential, Research Tool Creation, Pre-research Implementation

\section{Introduction}

Due to changes in the demographic structure of the Czech population, the issue of old age and seniors is becoming increasingly more topical. The increase in the length of life and a relatively low number of births lead to a significant increase in the proportion of people aged over 65 ; the second half of the $21^{\text {st }}$ century will thus belong to seniors. In 2011, the percentage of population aged over 65 was $15.5 \%$ according to the Czech Statistical Office. In 2060, their proportion will reach $34 \%$ of all citizens of the Czech Republic (1). There is an ever higher number of old people, and Czech society has not yet desisted from various negative prejudices and myths concerning seniors. These attitudes are formed as early as school age and are affected by different factors. Children may take over these sometimes positive but unfortunately mainly negative attitudes from their families, schools, parents, teachers, peers, the media etc. In this context, family upbringing and school education are very important and should promote intergenerational understanding. The main aim of the project entitled "Seniors in the Eyes of Children" was to create the semantic differential method and test it in practice in order to find out whether this method was suitable for examining the attitudes of primary-school pupils to old age and seniors.

\section{Relations between Children and Seniors}

People in today's society generally live longer, and the progress in medicine contributes to the fact that seniors are nowadays healthier and more active; at the same time, the birth rate is decreasing. All this leads to an increase in the number of elderly people and the ageing of our society (2). The population ageing has a number of negative consequences that are reflected in the attitudes of the younger generations to the elderly and in the attitude of the society to seniors. However, these attitudes and approaches are formed especially on the basis of various myths and a stereotypical perception of old age and elderly people which children take over from their parents and other people close to them. These negative ideas, myths and prejudices are often very misleading and, among other things, contribute to the worsening of intergenerational relationships. In bygone eras, when multiple generations lived together, children could see the respect for old age, noticed the need for mutual help and belonging etc. However, this family model no longer exists, with some exceptions; children encounter elderly people less and less frequently, and the two generations are drifting apart (3). Instead of intergenerational learning, respect for seniors, and the wisdom and usefulness of seniors, we rather hear of intergenerational conflicts, wars between generations and, unfortunately, discrimination against seniors by young people (2).

Old people are figuratively, sometimes literally cast aside. Each generation grows up in different conditions, and thus gains different life experience, opinions, attitudes, values and standards to a certain extent. These differences were not 
so apparent at a time when the world changed only slowly. Nowadays, however, with the continuous progress of modern science and technology, this intergenerational gap is widening even more because old people do not really understand the technological world. It is therefore very important that these two generations meet and share information, experience etc. If children, parents and grandparents live together, they can communicate more intensively, share life experience in practice, learn the importance of the existence of another person, coexist naturally and settle any conflicts directly (4). If these generations do not live together, children should at least meet their grandparents as often as possible, as grandparents play a crucial role in the family community in terms of the mutual affection between the two generations of parents. Thanks to the educational influence of grandparents, children can connect the present and the past, perceive traditions, values etc. By watching the attitudes of their parents to the grandparents, children learn to form their own attitudes which they will apply in relation to their own parents (5). Teaching children mutual understanding should not end with the completion of the school education; the development of intergenerational understanding should be lifelong. The society should focus on activities leading to the understanding of the needs of elderly people and the ageing process by young people, as well as activities that will help familiarise the elderly with the world of the young, thereby resulting in a mutual understanding (6).

\section{Semantic Differential}

Semantic differential is a research tool by means of which we can measure the psychological meanings which certain objects (mostly concepts) have for individuals. It is a known fact that if several people assess a single object, each of them will see the object differently. This method is focused on establishing the way in which people perceive concepts, where each such concept has a connotative as well as denotative meaning (7). Semantic differential is among psychosemantic methods, which strive to understand the individual meanings of words, and thus penetrate deeper layers of thinking and the feelings of the respondent, especially where the communication has an emotional as well as factual aspect. Understanding the meaning which the respondent assigns to certain words means understanding the respondent's world (8). A characteristic advantage of semantic differential lies in the possibility of penetrating the individual hidden meanings of concepts and in the fact that the respondents do not know the exact way in which their answers will be processed, and thus cannot intentionally distort the overall results (9).

The author of the method is the American professor Charles Osgood, who developed it together with G. J. Suci and P. H. Tannenbaum in 1957. The individual meanings of concepts are measured using a certain number of assessment scales. Respondents record their opinions of the assessed objects by choosing certain points on the scales, where both ends of the scales constitute a pair of opposing adjectives. By choosing a point on the scales, respondents convey the degree of the trait or characteristics expressed by the respective pair of adjectives. Numerical values are then assigned to the points on the scales (7).

Each concept can be assessed in terms of three dimensions or factors, namely the factor of evaluation, the factor of potency and the factor of activity. The factor of evaluation is the most important and can be interpreted as positive or negative (e.g. pleasant - unpleasant, good - bad). The factor of potency can be interpreted as the strength of the concept, i.e. whether the concept seems to be strong and dominant or weak (e.g. coarse - soft, heavy - light). The factor of activity can be interpreted as a relation of the concept to movement and change (e.g. active - passive, slow - fast). If we identify these three factors for a concept, we establish the concept's individual psychological meaning, according to Osgood. The meanings of individual concepts can then be graphically depicted as points in a three-dimensional space, called the semantic space. It is a space in which the positions of the evaluated concepts are marked using the semantic differential method; on the basis of the proximity or distance between the concepts, the degree of the concepts' similarity or difference can be interpreted. We can also calculate the linear D distance, using which we can establish the distances between the individual concepts in the semantic space. The calculated values of the linear distance are generally recorded in a D-matrix, which then indicates which concepts are close and which are distant in terms of their meanings (7).

In the creation of the semantic differential, it is necessary to adhere to a certain sequence of the individual steps. The first step is the selection of the concepts we want to evaluate. These concepts should be related. The next step is the selection of a suitable number of the scale points. Most often, seven-point scales are used. It is also necessary to determine suitable bipolar adjectives. In the original semantic differential, Osgood divided the adjectives into the factors, where in each factor there was the same number of adjectives. According to other authors, however, it is not always necessary to select all three factors; sometimes it is enough to use one or two depending on the concept under evaluation (10). According to Ferjenčík (11), the selection of adjectives should meet two requirements - representativeness and relevance. Representativeness means the fact that the chosen adjective relatively clearly represents only one of the dimensions of the semantic space. Relevance means that the adjective should be related to the concept under evaluation in terms of content. However, Osgood suggests that even relatively distant adjectives should be used because this is a projective method. The last step is the arrangement of the adjectives on a bipolar scale. All positive characteristics have to be on one end of the scale and all negative characteristics on the other. In order to reduce the risk of stereotypical assessment, some of the scales may be presented in reverse. This means that the end points of the scales are reversed. However, this has to be taken into account when processing the results (10). 


\section{Project Design and Implementation}

To measure the attitudes of pupils at primary schools in Olomouc, we chose the method of semantic differential, supplemented with questionnaire-type items related to the issue in terms of content. 73 sixth- and ninth-grade pupils participated in the pre-research. The semantic differential creation first required studying specialised literature, based on which we prepared the research tool itself. The first step was to create a set of concepts which the primary-school pupils would assess. The set of concepts was created on the basis of brainstorming; of several dozen concepts, we chose eleven that were the most suitable in relation to the issue. The next step was to select the number of the scale points. In this case, we chose the most frequent scale, i.e. a seven-point scale. The most difficult task was the last step, in which we had to determine the number of semantic differential factors and suitable bipolar adjectives using which the pupils would evaluate the chosen concepts. In the selection of adjectives, we used the original list of adjectives created by the semantic differential founder himself, C. Osgood, as well as adjectives used in previous researches for inspiration. We preserved the semantic differential structure proposed by C. Osgood, i.e. a three-factor structure (the factor of evaluation, the factor of activity and the factor of potency). 4 scales were chosen for each factor:

- Factor of evaluation: useful - not useful, valuable valueless, beautiful - ugly, entertaining - boring.

- Factor of activity: fast - slow, young - old, active passive, sharp - blunt.

- Factor of potency: strong - weak, close - distant, deep - shallow, wide - narrow.

The pupils assessed 11 concepts (parents, old person, love, old age, my school, wisdom, illness, me, joy, grandparents, loneliness) using twelve semantic differential scales. The record sheet was identical for each concept and is shown in Table 1, where adjectives marked with an asterisk constitute reverse scales, i.e. scales with reversed end points.

Table 1. Record sheet for the individual concepts of semantic differential

\begin{tabular}{|c|l|l|l|l|l|l|l|c|}
\hline useful & & & & & & & & not useful \\
\hline fast & & & & & & & & slow \\
\hline weak* & & & & & & & & strong \\
\hline valuable & & & & & & & & valueless \\
\hline young & & & & & & & & old \\
\hline close & & & & & & & & distant \\
\hline ugly* & & & & & & & & beautiful \\
\hline active & & & & & & & & passive \\
\hline deep & & & & & & & & shallow \\
\hline entertaining & & & & & & & & boring \\
\hline blunt* & & & & & & & & sharp \\
\hline wide & & & & & & & & narrow \\
\hline
\end{tabular}

The pre-research was conducted in two sixth- and two ninth-grade classes in Olomouc. Upon previous agreement with the homeroom teachers, the pre-research was in each case assigned in the type of lessons that are regularly conducted by homeroom teachers in order to address current issues and other matters relating to the class. This was done in order to avoid influencing the pupils' responses by conducting the pre-research in a specific subject. The pupils had 45 minutes to complete the semantic differential, and it was given to the pupils directly by the researcher. The homeroom teacher was there to ensure the presence of a person with a natural authority. This way we tried to prevent a situation where the pupils might complete the semantic differential too negligently if only a stranger was present. As Radko Pöschl (9) states in the instructions for working with semantic differential, it is advisable to briefly present the objective of the research at the beginning. The objective was presented as follows: to map how the pupils perceived the meanings of the chosen concepts. It was unnecessary to provide more information, as any more details might have influenced the pupils' responses. After the brief introduction of the objective, it was necessary to present to the pupils the semantic differential method and point out that it was not a knowledge test and that there were no correct or wrong answers. The only correct answer was an honest response of each pupil. For the purposes of the research implementation, it was very important to familiarise the pupils with the basic instructions for working with semantic differential. In order to make the explanation as understandable as possible, we made a practical demonstration of the procedure. Then we summarised the basic principles of the completion of the semantic differential, such as: select only one point on each scale, respond according to the very first idea that comes to mind and not think of an answer for too long, evaluate all concepts on all scales, and work independently. In conclusion, we again noted that we did not want to give any marks to the pupils and that we merely wanted to map their attitudes. The researcher was present all the time to assist any pupil who would need help.

\section{Evaluation and Results of the Project}

73 pupils participated in the pre-research, and the return rate of the completed semantic differential record sheets was one hundred percent. Such a return rate was ensured because the researcher distributed the semantic differential to the pupils directly. Of the total number, we had to disqualify two record sheets because they were incomplete. A total of 71 semantic differential record sheets were evaluated. In the pre-research, we focused on the suitability and adequacy of the research tool, its testing in practice, and verifying its validity and reliability. In order to establish the validity of the research tool, we used the statistical method of cluster analysis, namely the explorative cluster analysis - the extraction of the main component and a normalised VARIMAX. In order to establish reliability, we used the calculation of Cronbach's alpha coefficient. 
As part of the pre-research, semantic differential was tested in practice and we can say that it is a suitable method for sixth- and ninth-grade pupils. It turned out that the pupils had understood the research tool and the way of its completion, and there was no problem during the pre-research that might constitute an impulse for us to choose a different research tool. Cronbach's alpha coefficient exceeded 0.8 , and we can thus state that the chosen research tool is reliable. Unfortunately, the construct validity of the scales did not turn out for each scale in such a way that we could consider the semantic differential to be valid. Upon consultation with experts, we have several options how to do further work in order to be able to use semantic differential as a valid tool for the research itself. One option is to exclude the scales where construct validity was not proved. Another option is to replace the scales with other scales, or to combine the factor of activity and the factor of potency into one and prepare a two-factor semantic differential.

The constructional validity of the scales of the evaluation factor has been verified, therefore we present partial results only in this factor. The arithmetic means were calculated for the evaluation factor with respect to the concepts being evaluated. The results (Table 1) show how the pupils evaluated these concepts. The lower the value, the more negative the evaluation, and, conversely, the higher the value, the more positive the evaluation. The scales were prepared as seven-point scales; point 1 thus expresses the most negative evaluation and point 7 constitutes the most positive evaluation. Point 4 represents a neutral evaluation.

Table 2. Arithmetic means for the evaluation factor in selected concepts under evaluation

\begin{tabular}{|c|c|c|}
\hline Concept & \multicolumn{2}{|c|}{ Evaluation factor } \\
\hline & Boys & Girls \\
\hline Parents & 6.7 & 6.3 \\
\hline Old person & 4.9 & 4.8 \\
\hline Old age & 4.2 & 3.5 \\
\hline My school & 4.5 & 4.5 \\
\hline Grandparents & 5.3 & 5.7 \\
\hline Me & 5.7 & 5.7 \\
\hline
\end{tabular}

In Table 2, we can see that the boys and the girls perceive the concepts of "my school" and "me" in the same way. The concept of "my school" was evaluated rather neutrally (4.5), while the concept of "me" was evaluated rather positively by the pupils (5.7). The pupils evaluated the concept of "grandparents" similarly to the concept of "me" (5.3 in the case of the boys and 5.7 in the case of the girls), and the concept of "parents" received the most positive evaluation (6.7 in the case of the boys and 6.3 in the case of the girls). The concept of "old person" was evaluated at a similar value by the boys (4.9) and the girls (4.8) - this concept was considered neutral - rather positive. The related concept of "old age" was perceived more negatively (the boys -4.2 , the girls -3.5$)$. Out of the selected concepts, the concept of "old age" was the only one evaluated at a value below 4 , i.e. rather negatively (only in the case of the girls). What is interesting is the finding that, with the exception of the concept of "grandparents", the girls evaluated all the concepts either identically to or more negatively than the boys. It is obvious that we cannot generalise the results of the pre-research; however, this was not the purpose. In the pre-research, we tested the research tool in practice and verified its validity and reliability. We also learned to work with semantic differential in terms of its creation, assignment and processing, and in terms of the assessment of results.

\section{Conclusions}

The attitudes of school-age children to old age and seniors are formed gradually, and their formation and development may be affected by different factors. In this context, a significant role is played not only by the family but also by the school, which is crucial in the establishment of relations to elderly people, in the understanding of the issue of old age, and in forming intergenerational understanding. The semantic differential method serves to map attitudes and measure hidden, connotative meanings of concepts, and we believe that on the basis of the conducted pre-research it is a suitable method for examining the attitudes of primary-school pupils to old age and seniors. Semantic differential is not used only in pedagogy; it can be applied on various research issues in the field of personality examination, consultancy or clinical, social or pedagogical psychology. It is sufficiently reliable, valid and flexible, and the data processing is fast and easy thanks to the advanced information technology (9). However, the preparation of the semantic differential as such is rather time-consuming and associated with many difficulties. In the case of our pre-research, particularly the construct validity of the scales seemed problematic, as it was not confirmed for all the scales proposed by us. This problem has been encountered by many researchers using the method of their own semantic differentials; that is why we had expected this, and we will now strive to correct the research tool so that it is valid and can be used in the research focused on establishing the attitudes of primary-school pupils to old age and seniors.

\section{Acknowledgements}

The contribution was made as part of the project of the Student grant competition No IGA_PdF_2015_027 entitled "Seniors in the Eyes of Children".

\section{REFERENCES}

[1] Čechů ubyde a zestárnou. Český statistický úřad. [Online] 2013. [cit. 2016-04-20] Available at:http://www.czso.cz/csu/t 
1862 Semantic Differential as One of the Research Tools Suitable for Establishing the Attitudes of Pupils to Old Age and Seniors

Z_nsf/i/cechu_ubyde_a_zestarnou_20130723.

[2] Senioři nepatří do starého železa. Ministerstvo práce a sociálních věcí. [Online] 2012. [cit. 2016-04-12] Available at: http://www.mpsv.cz/files/clanky/13111/TZ_Seniori_nepatri_ do_stareho_zeleza.pdf.

[3] Haškovcová, Helena. Fenomén stáríi. Praha : Havlíček Brain Team, 2010. ISBN 978-80-87109-19-9.

[4] Možný, Ivo. Rodina a společnost. Praha : Sociologické nakladatelství, 2008. ISBN 978-80-86429-87-8.

[5] Grecmanová, Helena. Obecná pedagogika II. Olomouc : Hanex, 2003. ISBN 80-85783-24-X.

[6] Haškovcová, Helena. Sociální gerontologie, aneb, Senioři mezi námi. Praha: Galén, 2012. ISBN 978-80-7262-900-8.
[7] Chráska, Miroslav. Metody pedagogického výzkumu: základy kvantitativního výzkumu. Praha : Grada, 2007. ISBN 978-80-247-1369-4.

[8] Pelikán, Jiří. Základy empirického výzkumu pedagogických jevů. Praha : Karolinum, 2011. ISBN 978-80-246-1916-3.

[9] Pöschl, Radko. Postoje žáků ke škole:dotazník pro žáky. Praha : Národní ústav odborného vzdělávání, 2011. ISBN 978-80-86856-70-4.

[10] Gavora, Peter a kol. Elektronická učebnica pedagogického výskumu. Bratislava : Univerzita Komenského, 2010. ISBN 978-80-223-2951-4.

[11] Ferjenčík, Ján. Úvod do metodologie psychologického výzkumu:jak zkoumat lidskou duši. Praha : Portál, 2010. ISBN 978-80-7367-815-9 